\title{
Long-standing Friendship, Dedicated Political Dialogue and Mutually Beneficial Cooperation as a Key for Thriving Economic Partnership Between Azerbaijan and China
}

\author{
Akram Zeynalli
}

The long-established and rich history of relations between the Azerbaijani and Chinese people dates back to the Ancient Silk Road. Our people maintained trade and cultural ties through the Ancient Silk Road as early as 2,500 years ago. A description of a beautiful Chinese lady in the poem called "The Seven Beauties" written by the greatest Azerbaijani poet Nizami Ganjavi in the twelfth century is also an evidence of the long-standing cultural ties between our peoples.

Diplomatic relations between Azerbaijan and China were established in 1992, and the official visit of H.E. Mr. Heydar Aliyev, the national leader and late President of the Republic of Azerbaijan, to China in 1994 laid a strong foundation for bilateral relations between our countries. Since then, Azerbaijan and China have been developing bilateral relations in the spirit of friendship, cooperation, mutual trust and respect and have strongly supported each other on the issues related to the vital interests and major concerns.

President Ilham Aliyev's official visit in 2005 and state visit in 2015 to China once again proved the mutual will of both heads of state to further develop and deepen bilateral relations. During those visits, many documents were signed, among which "Joint Declaration between the Republic of Azerbaijan and People's Republic of China" and "Memorandum of Understanding on Joint Encouragement of the Establishment of Silk Way Economic Belt between the Government of the Republic of Azerbaijan and the Government of the People's Republic of China" are of paramount significance with regard to steadily and rapidly expanding mutual cooperation between our countries and nations.

Our mutual political trust that has always strengthened and multifaceted cooperation has continuously deepened. In this regard, it is worth emphasizing the significance of recent high-level reciprocal visits as an indicator of prospering bilateral ties

This article was written on June 17, 2021.

\section{A. Zeynalli $(\bowtie)$}

Embassy of the Republic of Azerbaijan to the People's Republic of China, Beijing, China 
and intensifying political and economic dialogs between Azerbaijan and China. The invitation to President Aliyev by President Xi to participate in the Second Belt and Road Forum for International Cooperation in April of 2019, as well as a very productive bilateral meeting held between the two heads of state during the Forum, can be considered as an accurate indicator of high-level political will and commitment to the expansion of ties between our countries. Moreover, it has to be emphasized that the Chairman of the Standing Committee of the National People's Congress of the PRC Li Zhanshu, the State Councilor and Minister of Foreign Affairs of the PRC Wang Yi and the Head of the International Relations Department of the Central Committee of the CPC Song Tao made official visits to Azerbaijan in 2019, which also contributed to further consolidation of political trust between our countries.

At the same time, in 2019, successful organization of the seventh meeting of Azerbaijan-China Intergovernmental Commission on Trade and Economic Cooperation in Beijing, as well as participation of the delegation from Azerbaijan, headed by the Deputy Prime Minister Shahin Mustafayev, in the second China International Import Expo in Shanghai, the official visit of the former Deputy Prime Minister Hajibala Abutalubov to attend the Closing Ceremony of International Horticultural Exhibition in Beijing, participation of the Minister of Defense of Azerbaijan Zakir Hasanov in the work of the ninth Beijing Xiangshan Forum and official visit of the Vice-President of the Heydar Aliyev Foundation of Azerbaijan Leyla Aliyeva to participate in the Conference on Dialog of Asian Civilizations, all gave an impetus to raise AzerbaijanChina cooperation to a qualitatively new level and brought about rapidly growing dynamics in bilateral relations.

As we all know, the COVID-19 pandemic created numerous challenges for the whole world, including Azerbaijan and China, starting from early 2020. Both countries took very important, strict and timely measures to curb the spread of the virus, to strengthen communication and coordination and to support international cooperation in prevention and control measures. Azerbaijan and China displayed exemplary work by cooperating during the hard times, joining hands to fight against the pandemic and helping each other and other countries in need to triumph over the virus.

As President Aliyev stated, "Azerbaijan has been and continues to be an active supporter of broad international cooperation in the fight against the pandemic", and with respect to that, Azerbaijan has provided financial and humanitarian assistance to more than 30 countries. Similarly, Azerbaijan has always been by China's side to support its fight against COVID-19 and applauded the preventive measures taken by the Chinese government. The Azerbaijani government and people regularly expressed their solidarity with Chinese people during the tough moments of the battle against the virus in China. President Ilham Aliyev, as well as many other highranking officials from Azerbaijan, sent letters of sympathy and solidarity to their Chinese counterparts and expressed readiness to provide any assistance if needed. The city of Sumgait in Azerbaijan sent 20 tons of humanitarian assistance to its sister cities-Mianyang and Xi' an-in China, and a lot of Azerbaijani people joined to the virtual support campaign "Wuhan Jiayou, Zhongguo Jiayou". ${ }^{1}$ The Azerbaijani 
cargo airline "Silk Way Airlines" was among the few foreign companies which continued its operations in China during the peak of the infection, and afterwards played an important role in transportation of medical supplies and equipment.

When the whole world faced the same situation and the virus started to spread globally, we witnessed the same approach of support and cooperation from Chinese side toward other countries, including Azerbaijan. The Chinese government has shown a special attitude to Azerbaijan during the purchase of various protective equipment, devices and medicines from China and has provided the highest level of support in all matters. The Ministry of Foreign Affairs and National Health Commission of the People's Republic of China co-organized an online conference for experts from Azerbaijan and China to share Chinese experience in infection prevention and treatment of the COVID-19 patients. In this way, our government and experts were ready to face the pandemic and took all necessary measures in time to ensure the safety of the Azerbaijani people. In addition, a medical team comprised of ten specialists with experience in fighting against COVID-19 in Wuhan, which was considered the epicenter of the epidemic in China, was sent to Azerbaijan for 14 days by the Chinese government. In the next stage, the Chinese side provided a high level of support to Azerbaijan in purchasing the vaccines produced in China and in delivering them to our country, organizing the shipment of 150,000 doses of vaccines to Azerbaijan as a humanitarian aid.

As a result of the travel restrictions and other measures imposed by both governments to combat the pandemic, high-level reciprocal visits between Azerbaijan and China have not taken place since the start of the pandemic. However, our countries continued cooperation through other means, and despite the fact that the bilateral trade naturally went down in 2020 as an obvious impact of the pandemic, there have been numerous opportunities for us to explore and collaborate on in order to achieve the utilization of the full potential to enhance our economic partnership.

It has to be noted that the mutual trust, dedicated political dialog and friendship between President Ilham Aliyev and President Xi Jinping play an important role also in developing bilateral economic ties and trade. Currently, more than 180 Chinese companies are registered in Azerbaijan, and as of today, China has invested about more than USD 820 million in the economy of Azerbaijan. Azerbaijan, in turn, has invested more than USD 1.7 billion in the Chinese economy. Big Chinese ICT companies such as Huawei and ZTE are operating successfully in Azerbaijan, and it is worth noting that the regional office of Huawei is located in Azerbaijan. It is also very important to mention the role of Azerbaijan in the China Intergovernmental Commission on Trade and Economic Cooperation in establishing close contacts between the businesses from both sides and solving the problems faced by companies in each country. The seventh meeting of the Commission was held in February 2019 in Beijing, where tangible results were achieved and concrete goals were determined for the future cooperation.

Azerbaijan has rich oil and gas reserves, which helped our economy to expand rapidly in the 1990s, and investments made in Azerbaijan's energy sector brought about diverse dividends and opportunities to develop other sectors. One of the priorities before the government of Azerbaijan now is to diversify the economy by

1"Go Wuhan, Go China". 
improving different sectors and reducing dependence on hydrocarbon resources. Taking into account the fact that the government is vigorously trying to improve the non-oil sector in the country, Azerbaijan now focuses more on foreign trade and investments in other fields. In this regard, our productive, multidimensional and results-oriented cooperation with China also contributes to the Azerbaijani government's strategy to diversify national economy by boosting trade and investment.

Azerbaijan is China's main trading partner in the South Caucasus and we are committed to improve our trade relations further. In this respect, it is worth mentioning that Azerbaijan has always been represented in the China International Import Expo with a large pavilion, a substantial number of companies and a large delegation comprised of high-level government officials since the first Expo was held. Even during the last Expo in November of 2020, we set up a significantly large pavilion and showcased food and agricultural products of Azerbaijan, despite the fact that many other countries failed to participate due to the pandemic. We opened Azerbaijan Trade Houses in Qingdao, Luzhou and Lianyungang, as well as Azerbaijan Wine Houses in Shanghai and Urumqi. Currently, negotiations on opening new trade and wine houses in other regions of China are being held with relevant authorities, so that we can have further access to more Chinese customers soon. Undoubtedly, Azerbaijan is keen on improving its trade relations with China, and we strongly believe that we will be able to achieve more positive results in terms of trade between our countries in the near future.

Azerbaijan was one of the very first supporters of the Belt and Road Initiative, and as a testimony to our aspirations to jointly implement this Initiative, Azerbaijan has invested a great deal in infrastructure projects both in the country and in the region in order to become a regional transit and logistics hub located at the crossroads of Asia and Europe. Developing into a very crucial country along the Belt and Road, Azerbaijan now offers better options for the efficient and economically viable transportation of goods from China to Europe and vice versa. In this sense, Azerbaijan has initiated Trans-Caspian International Transport Route and carried out several important infrastructure projects such as the Baku-Tbilisi-Kars Railway, Baku International Sea Trade Port and Alyat Free Trade Zone. It should be mentioned that several block trains from Xi' an have already passed through Azerbaijan on their way to Europe, and this route is becoming more and more active as our economic cooperation deepens. Furthermore, there are now direct passenger flights between Baku and the Chinese cities of Beijing and Urumqi, as well as direct cargo flights between Baku and Shanghai, Hong Kong, Tianjin and Zhengzhou, which make Azerbaijan an even more attractive place for Chinese companies to do business.

It is crucial to note that the first ever cargo train left from the China-SCO Demonstration Zone in Qingdao on January 31, 2021, in the direction of Baku, Azerbaijan. It is a well-known fact that China initiated many special economic zones, which create vast opportunities for businesses to benefit, and the China-SCO Demonstration Zone in Qingdao is definitely one of the most promising projects in that respect. It will not only enhance cooperation among SCO countries, but will also significantly contribute to the development of the BRI. Azerbaijan is also a very active member of the "SCO Family" and successfully cooperates with all member states including 
China. The construction of the China-SCO Demonstration Zone started in 2018 at the initiative of President Xi Jinping to bring SCO countries closer and to further encourage cooperation among them. As we marked the sending of the first cargo train from Qingdao to Azerbaijan in January of this year and as we witness rapid improvements going on in terms of the Zone development, we can confidently affirm that this initiative is already yielding positive results.

It is important to mention that this train traveled through the Trans-Caspian International Transport Route and eventually reached the Baku International Sea Trade Port, which is the biggest port on the Caspian Sea. Compared to traditional maritime shipping, it took about a third of the time for this train to arrive its final destination. Transportation time is significantly reduced when the goods are carried through the Trans-Caspian International Transport Route, and this certainly brings about further benefits for businesses. Today, it is gratifying to see that the Trans-Caspian International Transport Route, also known as the Middle Corridor, is becoming a more and more active part of the BRI day by day.

Azerbaijan also invested in another international transportation project-the north-south transportation corridor-and the countries situated on the east-west and north-south transportation corridors use the territory of Azerbaijan in order to transport their goods. Therefore, our investments in modern transportation infrastructure help not only to increase our economic potential and to provide services for our friends, partners and neighbors, but also create a unique opportunity for trade, tourism, transportation, and it unites people and countries; the countries become interdependent, and this serves the goal of peace and stability. Today, Azerbaijan provides transit opportunities for a growing number of countries. By creating modern transportation and logistics infrastructure, we not only transform our country into an important transportation hub, but also contribute to cooperation with the countries involved in the east-west and north-south corridors.

There is no doubt that the Belt and Road Initiative will bring about vast opportunities and dividends for participating countries in terms of infrastructure and transportation. However, it is worth noting that the initiative does not only create opportunities in transportation but also enhances trade, tourism, people-to-people contacts, which contributes to the cause of stability, security and peace in the world. The BRI follows China's traditional preference for mutual benefit, common interests and cooperation for common development. Despite the volatility of the global situation, it advocates a vision of respecting others' interests while pursuing one's own and advances the common interests of all. In this regard, the Azerbaijani side stands ready to work with China to use the BRI as an opportunity to align the development plans of the two sides, deepen cooperation in infrastructure construction and other extensive areas, expand cultural, educational and local exchanges and enhance mutual understanding and friendship. We believe that by connecting peoples, countries and economies, this global initiative creates favorable conditions for win-win cooperation and ensures peace and prosperity in the whole world.

Azerbaijan is keen to cooperate with other countries to attract more investment to its open and transparent market where entrance requirements are quite easy and the 
business climate is being continuously improved through a diverse set of reforms and policies. Chinese investment is no exception in this regard, and deepening cooperation, especially during the recent period, is a clear indicator for Azerbaijan's willingness to have more Chinese companies operating in Azerbaijan. During the last bilateral meeting held between President Ilham Aliyev and President Xi Jinping in April of 2019, President Aliyev mentioned that we would like to see more Chinese companies and investors doing business in Azerbaijan and also participating in different projects as contractors. Therefore, we welcome more Chinese investors to our country, and we are more than confident that the investment environment in Azerbaijan is convenient and competent for them to run their businesses.

Taking into consideration the fact that stability is critical for achieving continuous economic development, it is worth mentioning that Azerbaijan is a politically and economically stable country where the well-being of the people improves day by day. The economy of Azerbaijan thrives at increasing rate, and the government's committed economic policy ensures the country's sustainable development.

In November of 2020, the conflict in the South Caucasus came to an end and Azerbaijan liberated its territories, which had been under occupation of Armenia for almost 30 years. Unfortunately, almost all of these cities and districts were completely destroyed, and their infrastructure demolished during the occupation. Thankfully, under the direct control and effective supervision of President Ilham Aliyev, the Azerbaijani government is preparing plans and working on projects to restore all liberated territories and return life to normal there. In this sense, Azerbaijan will also invite foreign countries and companies to participate in restoration process and invest in liberated lands. Accordingly, we will actively cooperate with Chinese friends and businesses, which are interested in getting involved in the revival process of our newly liberated territories.

The peace settlement achieved in November of last year will allow for the construction of a new corridor linking the mainland of Azerbaijan to its landlocked exclavethe Nakhchivan Autonomous Republic. Transiting directly across the Caucasus, this new corridor will significantly cut road transportation time from east to west and vice versa, and will complement the Baku-Tbilisi-Kars Railway and facilitate trade and business. This cross-country route will pass from the port of Baku on the coast of the Caspian Sea, then through newly liberated territories and-crucially-through a soon-to-be opened transport corridor to arrive at Nakhchivan. The line then continues directly into and through Turkey and onto the Mediterranean Sea and Europe. Clearly, this new corridor will play an important role in terms of connectivity along the Belt and Road route and bring about further opportunities for Azerbaijan and China to expand cooperation in transportation and logistics.

Azerbaijan never considered the BRI as an initiative targeting only transportation and infrastructure development, but also as a mechanism or a platform for bringing nations closer and improving people-to-people contacts. In this sense, Azerbaijan pays great attention to the development of tourism industry too, and with respect to that, we have introduced a simplified visa regime for Chinese tourists. It is worth mentioning that the number of Chinese tourists visiting Azerbaijan had been steadily 
increasing before travel restrictions were imposed due to the COVID-19 pandemic. There is no doubt that the "Memorandum of Understanding on Simplifying Group Visits of Chinese Tourists to Azerbaijan between the State Tourism Agency of the Republic of Azerbaijan and the Ministry of Culture and Tourism of the People's Republic of China" signed in March of 2019 will positively contribute to the number of Chinese tourists traveling to Azerbaijan during the post-pandemic period.

It should be emphasized that the provinces and cities of China are developing rapidly, and their sustainable, solid and robust economic growth creates vast opportunities for other countries to actively cooperate with them and reap the benefits of successful partnership. The local governments of cities and districts of Azerbaijan also work closely with the local governments of regions and provinces of China to enhance economic cooperation and reach win-win results. In view of this, we have established friendly and mutually advantageous relations between several cities of Azerbaijan and China, signed documents on sister-city relationships and will continue to make an every effort to further initiate and promote such good practices. In general, China's economy is developing rapidly, and several well-known financial organizations and research centers have already forecasted that China will have the largest economy in the world very soon. In this respect, all countries are willing to work with China to profit from mutually beneficial cooperation, and Azerbaijan is not an exception. We are always ready to work together with our Chinese friends to consistently improve our bilateral economic ties, to achieve rapidly increasing trade turnover and, consequently, to take our comprehensively developing relations to a higher level.

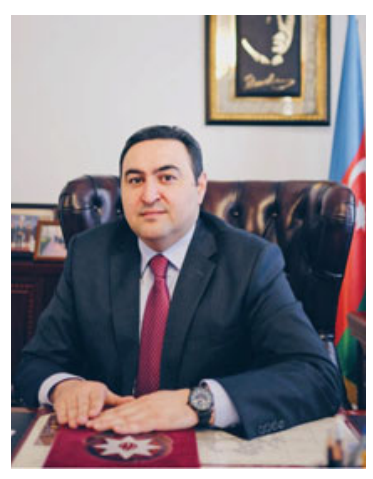

H.E. Mr. Akram Zeynalli is the Ambassador Extraordinary and Plenipotentiary of the Republic of Azerbaijan to the People's Republic of China. He has over 20 years of experience as a diplomat in the Government of Azerbaijan. He has been serving as ambassador to China since 2017. In 2012, he was appointed the ambassador of the Republic of Azerbaijan to the Swiss Confederation and finished his term in 2017. During 1999-2012, he worked in different departments at the Ministry of Foreign Affairs of the Republic of Azerbaijan, as well as served for the diplomatic missions of Azerbaijan in Brussels, Athens and Geneva. Ambassador Zeynalli received his degree in International Law and International Relations from Baku State University. 
Open Access This chapter is licensed under the terms of the Creative Commons AttributionNonCommercial-NoDerivatives 4.0 International License (http://creativecommons.org/licenses/bync-nd/4.0/), which permits any noncommercial use, sharing, distribution and reproduction in any medium or format, as long as you give appropriate credit to the original author(s) and the source, provide a link to the Creative Commons license and indicate if you modified the licensed material. You do not have permission under this license to share adapted material derived from this chapter or parts of it.

The images or other third party material in this chapter are included in the chapter's Creative Commons license, unless indicated otherwise in a credit line to the material. If material is not included in the chapter's Creative Commons license and your intended use is not permitted by statutory regulation or exceeds the permitted use, you will need to obtain permission directly from the copyright holder.

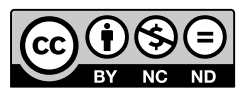

